\title{
ANALISIS SAFETTY FACTOR RODA GIGI PAYUNG UNTUK ALAT PENGERIK GARAM
}

\author{
Meri Rahmi \\ Politeknik Negeri Indramayu, Indramayu \\ Email:meri@polindra.ac.id \\ Dedi Suwandi \\ Politeknik Negeri Indramayu, Indramayu \\ Email: dedi@polindra.ac.id \\ Badruzzaman \\ Politeknik Negeri Indramayu, Indramayu \\ Email: badruzzaman@polindra.ac.id
}

\begin{abstract}
ABSTRAK
Garam merupakan salah satu komoditas yang strategis karena sangat dibutuhkan oleh orang banyak. Peningkatan kebutuhan terhadap garam di Indonesia semakin meningkat berbanding lurus dengan meningkatnya jumlah penduduk dan jumlah industri besar pengolahan garam di Indonesia. Terjadinya impor garam karena peningkatan kebutuhan dan kegunaan garam pada industri dan rumah tangga. Salah satu kota/kabupaten yang menjadi sentra penghasil garam kedua setelah Cirebon adalah Kabupaten Indramayu. Kabupaten ini mampu mensuplai kebutuhan garam nasional. Perancangan alat bantu pengerik garam yang diperuntukkan untuk petani garam di Kabupaten Indramayu diharapkan mampu menggantikan alat konvensional yang saat ini sering digunakan digunakan petani garam. Sistem kerja alat ini adalah dengan menggunakan mekanisme roda gigi payung dan lurus sehingga mampu secara axial memutar alat pengerik yang dirancang seperti sikat. Berdasarkan hasil perhitungan, roda gigi yang dibuat untuk memenuhi kebutuhan alat bantu ini adalah roda gigi dengan modul 2, jumlah roda gigi 20 dengan ketebalan roda gigi adalah $40 \mathrm{~mm}$. Tenaga dan beban yang dikeluarkan oleh petani bisa berkurang hingga $50 \%$ dari alat konvensional yang biasa digunakan saat ini. Analisis kekuatan dan safety factor terhadap alat ini telah dilakukan menggunakan FEA (Finite Element Analysis) dengan bantuan software solidworks. Hasil analisis menunjukkan bahwa roda gigi payung yang digunakan cukup kuat untuk mengerik garam untuk kedalaman $50 \mathrm{~mm}$.
\end{abstract}

Kata kunci: pengerik garam; efisiensi; roda gigi; FEA.

\begin{abstract}
Salt is a strategic commodity, because it is needed by many people. The increasing demand for salt in Indonesia is increasing directly proportional to the increase in population and the number of large salt processing industries in Indonesia. The occurrence of imports of salt due to an increase in the need and use of salt in industries and households. One of the cities / districts that became the second salt producing center after Cirebon was Kabupaten Indramayu. This regency is able to supply national salt needs. The design of salt scraper tools intended for salt farmers in Kabupaten Indramayu is expected to be able to replace conventional tools which are currently used by salt farmers. The working system of this tool is to use the bevel and spur gear mechanism so that it is able to axially rotate the scraper designed like a brush. Based on the results of calculations, the gears made to meet the needs of this tool are gears with module 2, the number of gears 20 with a thickness of gears is $40 \mathrm{~mm}$. Power and the burden incurred by farmers can be reduced by up to $50 \%$ from the conventional tools commonly used today. Strength analysis and safety factor for this tool have been carried out using FEA (Finite Element Analysis) with the help of solidworks software. The analysis shows that the umbrella gears used are strong enough to cut salt to a depth of $50 \mathrm{~mm}$.
\end{abstract}

Keywords: salt brakes; efficiency; gears; FEA.

\section{PENDAHULUAN}

Garam merupakan salah satu komoditas yang strategis, karena sangat dibutuhkan oleh orang banyak. Tingkat kebutuhan konsumsi garam Indonesia semakin meningkat sebanding dengan meningkatnya 
jumlah penduduk dan jumlah industri besar pengolahan garam di Indonesia. Gambar 1 menjelaskan peningkatan konsumsi garam rata-rata 2-10 persen per tahun. Berdasarkan data dari Direktorat Jenderal Industri Agro dan Kimia (2012), tahun 2011 kebutuhan garam mencapai 3.400.000 ton dan produksi garam mencapai 1.100.000 ton. Perkembangan garam impor digunakan tidak hanya untuk kebutuhan industri tetapi untuk memenuhu kebutuhan konsumsi. Untuk memenuhi kebutuhan konsumsi sisanya diandalkan dari produksi garam rakyat [1]. Salah satu kota/kabupaten yang menjadi sentra penghasil garam kedua setelah Cirebon adalah Kabupaten Indramayu untuk memenuhi kebutuhan garam nasional. Produksi garam konsumsi nasional tahun 2014 mencapai 2,19 juta ton, berasal dari PT Garam (Persero) sebesar 315 ribu ton dan garam rakyat sebesar 1,88 juta ton. Garam rakyat merupakan produksi yang berasal dari kabupaten/kota Pemberdayaan Usaha Garam Rakyat (PUGAR) dan Non PUGAR (swadaya masyarakat). Produksi garam rakyat tahun 2014 mencapai 2,50 juta ton, untuk mendapatkan garam siap pakai maka garam rakyat masih melalui proses penguapan sampai garam benar-benar kering sehingga volume produksi akan berkurang 25 persen. Sehingga volume produksi garam rakyat tahun 2014 menjadi 1,88 juta ton [2].

Penurunan kualitas dan kuantitas garam dimulai dari produsen garam yang dipanen oleh petani garam. Banyak kendala yang dihadapi oleh petani garam dalam memproduksi garam dengan kualitas dan kuantitas garam rakyat. Salah satu kendalanya adalah proses pengerikan garam setelah melewati proses pengendapan air lain hingga menjadi garam. Penggunaan alat pengerik garam yang konvesional berupa sikat dan didorong membutuhkan tenaga dan waktu kebih besar dan lebih lama. Dengan luas lahan setiap petaknya $3 \mathrm{mx} 15 \mathrm{~m}$ atau $4 \mathrm{mx} 12 \mathrm{~m}$ sangat membutuhkan tenaga dan waktu yang baik [3]. Penurunan kualitas dan kuantitas garam dimulai dari produsen garam yang dipanen oleh petani garam. Banyak kendala yang dihadapi oleh petani garam dalam memproduksi garam dengan kualitas dan kuantitas garam rakyat. Penggunaan alat pengerik garam yang konvensional berupa sikat dan didorong sehingga membutuhkan tenaga dan waktu kebih besar dan lebih lama. Proses pengerikan garam merupakan salah satu tahap dari beberapa tahap yang harus ada pada proses pembuatan garam. Proses pengerikan masuk pada tahap panen garam. Akan tetapi pada tahap panen ini, jarang tersentuh dengan penggunaan teknologi. Pemanfaatan teknologi lebih banyak dipakai pada tahap proses pengeringan garam, kristalisasi garam dan peningkatan kualitas garam.

Peningkatan kualitas air yang dilakukan pada proses kristalisasi telah meningkatkan kualitas garam denga kadarr $\mathrm{HCl}$ dari $90 \%$ menjadi $97 \%$ [5]. Pembuatan sistem tambak garam dengan tipe getrape pada proses kristalisasi mampu menjernihkan hasil garam [6]. Kadar $\mathrm{NaCl}$ dalam kandungan garam meningkat setelah dilakukan proses rekristalisasi sebesar $435 \mathrm{ppm}$ atau 99,36\% dari hasil tanpa rekristalisasi sehingga memenuhi Standar Nasional Industri untuk garam konsumsi [7]. Penelitian lain tentang garam adalah pembuatan alat pemisah garam dan air tawar dengan menggunakan energy matahari yang menghasilkan rata-rata air tawar sebanyak 3,2 liter per hari. Sehingga alat ini mampu mensuplai kebutuhan air minum untuk dua orang dalam satu hari [8].

Berdasarkan beberapa paparan penelitian yang telah dilakukan di atas, rata-rata pemanfaatan teknologi untuk proses pengeringan dan proses kristalilasi garam. Belum ada penelitian yang mengkaji dan menerapkan teknologi untuk membantu tahap panen garam terutama proses pengerikan garam. Penelitian ini melakukan rancang bangun alat penegrik garam dengan sistem roda gigi payung lurus, Hal ini diharapkan mampu membantu untuk mengurangi tenaga manusia, menjadi lebih mudah dalam pengerikan garam. Sistem ini juga akan dilengkapi sistem pengumpulan yang terintegrasi dengan alat ini. Sampai saat ini, belum ditemukan sistem pengerikan garam pada masyarakat Indramayu khususnya penggunakan kemajuan alat dalam teknologi.

\section{METODOLOGI PENELITIAN}

Metode penelitian rancang bangun alat bantu pengerik garam dengan sistem roda gigi yang diperuntukkan bagi masyarakat Kabupaten Indramayu terdiri dari beberapa tahap. Adapun tahapan yang akan dilakukan dalam penelitian ini dapat dilihat pada Gambar 1. 


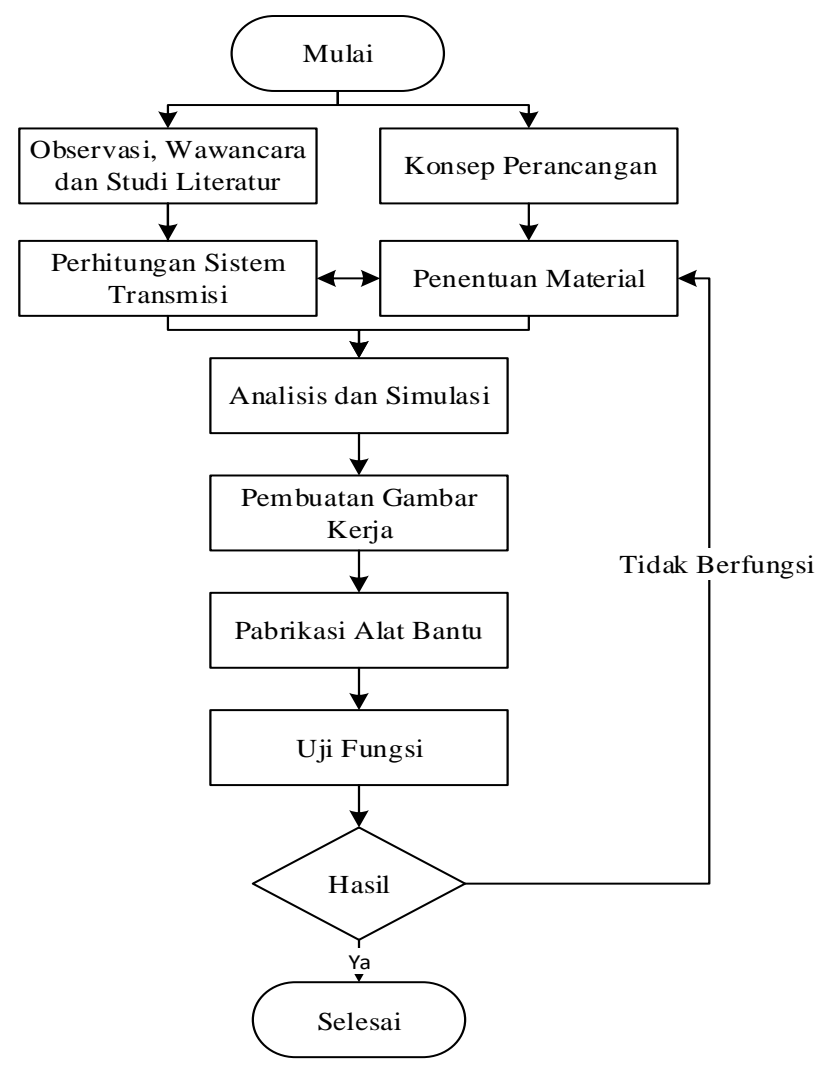

Gambar 1. Metodologi Penelitian

Tahapan pertama yang dilakukan pada penelitian ini adalah melakukan observasi dan melakukan wawancara langsung dengan petani garam yang ada di Kabupaten Indramayu. Hasil dari wawancara diterjemahkan kedalam bentuk rancangan sesuai dengan kebutuhan yang ada dengan pemanfaatan alat dan teknologi yang terbaru. Tujuan lainnya adalah mengenalkan kebaruan terhadap masyarakat sehingga masyarakat terbuka terhadap perubahan dan tidak alergi terhadap teknologi canggih. Saat ini, penggunaan alat bantu dan teknologi terbarukan hanya berada pada tahap proses pengeringan garam, pembuatan garam berkualitas dengan menambahkan unsur-unsur kimia [9].

Tahap selanjutnya adalah membuat konsep perancangan dengan sistem transmisi roda gigi. Beberapa alternatif rancangan dibuat, selanjutnya dipilih hasil konsep perancangan yang berfungsi dengan baik sesuai dengan kebutuhan. Perhitungan utama untuk konsep rancangan yang terpilih adalah perhitungan roda gigi payung lurus, poros dan pemilihan sistem bearing yang sesuai dengan rancangan. Bentuk roda gigi untuk dasar perhitungan dapat dilihat pada Gambar 2. Beberapa tahapan perhitungan utama dalam roda gigi payung lurus, antara lain dapat dilihat pada Tabel 1.

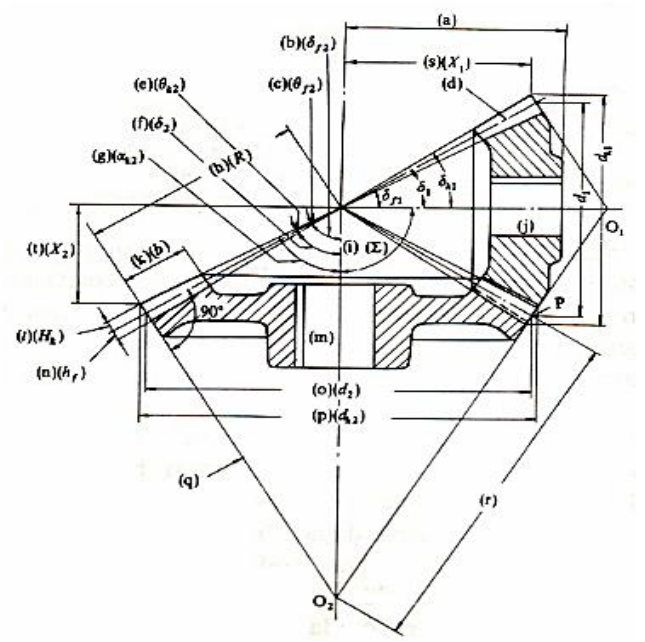

Gambar 2. Roda Gigi Payung Lurus [10] 
Tabel 1. Tahapan perhitungan roda gigi kerucut lurus [10]

\begin{tabular}{lclc}
\hline \multicolumn{1}{c}{ Nama } & Simbol & \multicolumn{1}{c}{$\begin{array}{c}\text { Roda Gigi } \\
\text { Penggerak }\end{array}$} & Roda Gigi Pengikut \\
\hline Sudut Tekan Normal & $\alpha \mathrm{n}$ & $=$ biasanya $20^{\circ}$ & \\
Pitch Melingkar & $\mathrm{i}$ & $=m x \pi$ & \\
Modul & $\mathrm{m}$ & $=t / \pi$ & \\
Jumlah Gigi & $\mathrm{z}$ & $\mathrm{Z}_{1}$ & $\mathrm{Z}_{2}$ \\
Jumlah Gigi Minimum & $\mathrm{zg}$ & $=\mathrm{z}: 25\left(\alpha \cdot \mathrm{n}: 15^{\circ}\right) ; \mathrm{z}: 9\left(\alpha \cdot \mathrm{n}: 25^{\circ}\right)$ \\
Sudut Pitch & $\delta$ & $\delta_{1}=\operatorname{arctg}\left(\mathrm{z}_{1}: \mathrm{z}_{2}\right)$ & $\delta_{2}=90^{\circ}-\delta_{1}$ \\
Kemiringan Kepala Gigi & $\delta_{\mathrm{k} 1}$ & $\delta_{\mathrm{k} 1}=\delta_{1}+\delta_{\mathrm{k}}$ & $\delta_{\mathrm{k} 2}=\delta_{2}+\delta_{\mathrm{k}}$ \\
Sudut Kepala Gigi & $\delta_{\mathrm{k}}$ & $=\operatorname{arctg}\left(\mathrm{h}_{\mathrm{h}} / \mathrm{Ra}\right)$ & \\
Sudut Kaki Gigi & $\delta_{\mathrm{d}}$ & $=\operatorname{arctg}\left(\mathrm{h}_{\mathrm{d}} / \mathrm{Ra}\right)$ & \\
Panjang Radius Pitch & $\mathrm{Ra}$ & $=\mathrm{dt} \mathrm{t}_{1}:\left(2 \cdot \sin \delta_{1}\right)$ & \\
Tinggi Gigi & $\mathrm{h}$ & $=(2.1 \mathrm{~s} / \mathrm{d} 2.4) \cdot \mathrm{m}$ & \\
Tinggi Kepala Gigi & $\mathrm{h}_{\mathrm{k}}$ & $=(1.1 \mathrm{~s} / \mathrm{d} 1.3) \cdot \mathrm{m}$ & \\
Tinggi Kepala Kaki & $\mathrm{h}_{\mathrm{d}}$ & $=\mathrm{m}$ & \\
Diameter Tusuk & $\mathrm{dt}$ & $=\mathrm{m} \mathrm{x} \mathrm{z}_{1}$ & $=\mathrm{m} \mathrm{x}_{2}$ \\
Diameter Kepala & $\mathrm{dk}$ & $=\mathrm{dt} \mathrm{z}_{1}+2 \mathrm{~h}_{\mathrm{k}} \cos \delta_{1}$ & $=\mathrm{dt}_{2}+2 \mathrm{~h}_{\mathrm{k}} \cos \delta_{2}$ \\
Diameter Dasar & $\mathrm{dd}$ & $=\mathrm{dt}_{1}-2 \mathrm{~h}_{\mathrm{d}} \cos \delta_{1}$ & $=\mathrm{dt} 2-2 \mathrm{~h}_{\mathrm{d}} \cos \delta_{2}$ \\
Lebar Gigi & $\mathrm{b}$ & $\leq \mathrm{Ra} / 3$ & \\
\hline
\end{tabular}

Perhitungan selanjutnya penentuan poros yang akan digunakan pada sistem transmisi pada roda gigi. Tahapan perhitungan poros antara lain [3], "P poros atas $=0,4 \times \mathrm{P}$ Manusia". Dalam mencari daya poros bagian tengah, dimana poros mendapatkan $60 \%$ daya dari poros bagian atas. "P poros tengah $=0,6 \times \mathrm{P}$ poros atas". Dalam mencari daya poros bagian tengah, dimana poros mendapatkan $60 \%$ daya dari poros bagian tengah "P poros bawah $=0,6 \mathrm{x}$ P poros tengah"

Hasil rancangan akan disesuaikan dengan hasil perhitungan yang didapatkan, kemudian dilakukan proses analisis dan simulasi dengan bantuan software solidworks 2016. Analisis dilakukan untuk mengetahui tegangan, regangan dan safety factor pada pengerik garam. Sebelum melakukan ini, terlebih dahulu penentuan material pada roda gigi, poros dan dudukan pendukung lainnya. Material yang dipilih adalah material yang tahan terhadap korosi, karena air laut dan garam merupakan penyebab korosi paling cepat pada material logam. Salah satu cara melapisi material yaitu dengan proses galvanis. Tahap selanjutnya adalah pembuatan gambar kerja (jobsheet) untuk proses pembuatan di bengkel Polindra. Mulai dari proses permesinan, perakitan dan finishing. Tahap terakhir adalah melakuakn uji fungsi pada alat pengerik garam.

\section{HASIL DAN PEMBAHASAN}

\subsection{Rancangan Alat Pengerik Garam}

Dasar dari konsep perancangan pengerik garam ini dari bentuk alat pengerik konvensional yang kemudian diadaptasi dengan menggunakan sistem transmisi roda gigi. Mekanisme dengan transmisi roda gigi payung menjadikan proses pengerikan garam menjadi lebih mudah. Dua alternatif konsep perancangan pada saat awal perancangan. Pemilihan rancangan yang dapat dilihat pada kemudahpakaian, kenyaman dan keamanan (safety factor). Bentuk rancangan alat pengerik garam yang terpilih dapat dilihat pada Gambar 3 dan Gambar 4. 

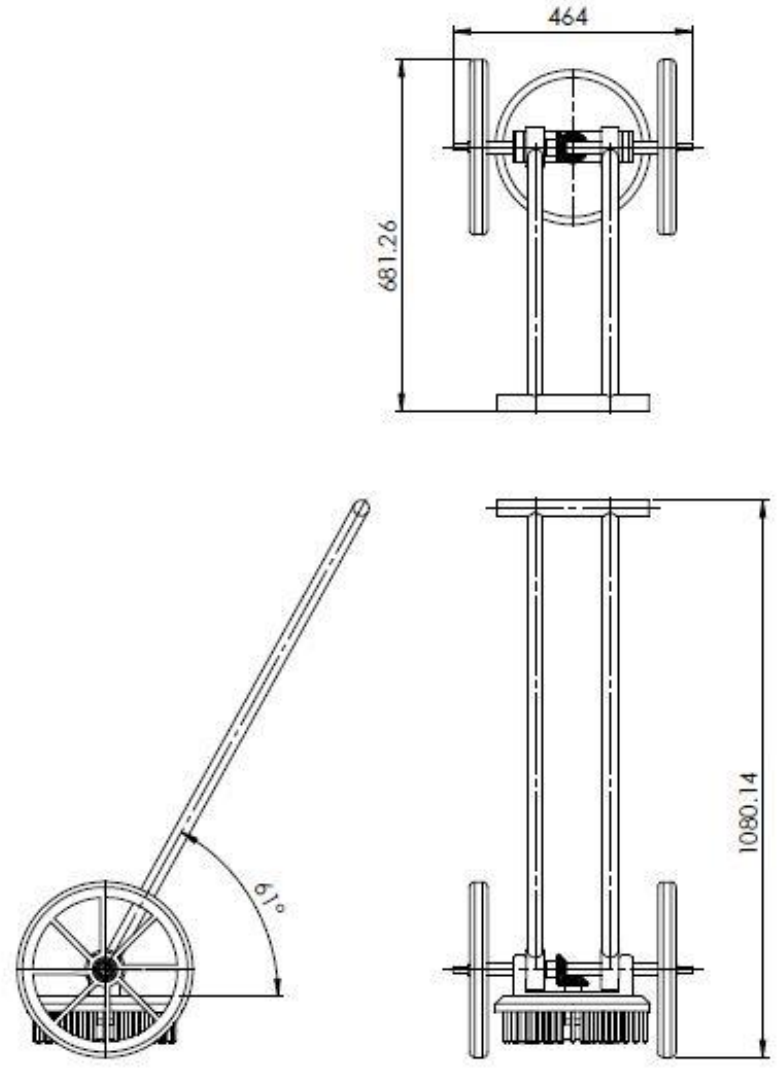

\section{Gambar 3. Alat Bantu Pengerik Garam-2D}

Bentuk rancangan bentuk pengerik garam yang terlihat pada Gambar 3, merupakan bentuk rancangan pengerik garam. Sisi ergonomi menjadi dan safety menjadi faktor utama. Ketinggian alat ini menyesuaikan dengan tinggi rata-rata orang Indonesia khususnya masyarakat Indramayu yaitu $\pm 1 \mathrm{~m}$. Selain itu, untuk pegangan yang dirancang mudah untuk digenggam, sehingga kekuatan penekanan dan daya dorong terarah untuk mengerik endapan garam.

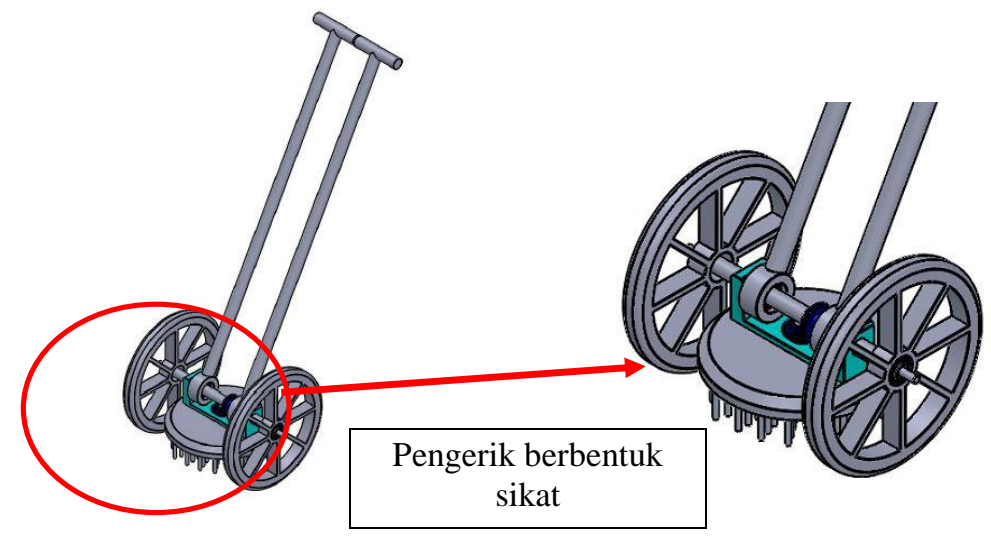

Gambar 4. Alat Bantu Pengerik Garam-3D

Bentuk rancangan pengerik pada Gambar 4 merupakan pengerik yang dirancang berbentuk sikat. Pengerik berbentuk sikat ini akan bergerak memutar akibat pengaruh dari daya dorong yang kemudian putaran diubah menjadi putaran axial dengan sistem roda gigi payung. Pengerik akan bergerak jika alat bantu didorong.

\subsection{Perhitungan Sistem Transmisi}

Rancangan roda gigi dengan modul 2 sudut tekan $20^{\circ}$ dan menggunakan bahan roda gigi SNC 21 dengan kekuatan tarik $80 \mathrm{~kg} / \mathrm{mm} 2$. Daya rencana adalah $0,35 \mathrm{~kW}$ dengan putaran $50 \mathrm{rpm}$, rasio roda gigi 
1, sudut posisi adalah $90^{\circ}$, radius pitch yaitu 40 dan sudut tekan $20^{\circ}$. Sehingga didapatkan jenis dan ukuran roda gigi yang akan dibutuhkan yaitu, modul 2, diameter roda gigi penggerak 56,57 mm, roda gigi pengikut 56,57 mm. Jumlah gigi untuk roda gigi penggerak 28 sama dengan jumlah roda gigi pengikut. Material yang digunakan adalah SNC 21.

Untuk perhitungan poros yang digunakan untuk dudukan roda gigi dan dan penggerak roda, berdasarkan perhitungan, maka didapatkan diameter untuk poros vertikal minimal $24 \mathrm{~mm}$ dengan panjang $200 \mathrm{~mm}$. Sedangkan poros horizontal didapatkan dimensi yaitu diameter minimal $24 \mathrm{~mm}$ dengan panjang minimal $500 \mathrm{~mm}$.

\subsection{Analisis dengan Finite Element Analysis (FEA)}

Hasil stress analysis yang akan terjadi pada alat bantu pengerik garam yang ditunjukkan pada Gambar 5 akibat beban yang diterima mampu menahan beban dari tekanan beban manusia. Berdasarkan hasil analisis stress/tegangan juga beban akibat proses saat pengerikan diwakili dengan perubahan warna yang ditampilkan, dimana semakin berubah menuju ke arah warna merah tegangan yang diterima semakin besar. Hasil perhitungan secara komputasi didapatkan tegangan maksimum yang terjadi yaitu tegangan yang ditunjukkan pada warna merah $\left(4,232 \mathrm{e}+005 \mathrm{~N} / \mathrm{mm}^{2}\right)$, sedangkan tegangan minimum yang bekerja ditunjukkan dengan warna biru $\left(6,368 \mathrm{e}-004 \mathrm{~N} / \mathrm{mm}^{2}\right)$.

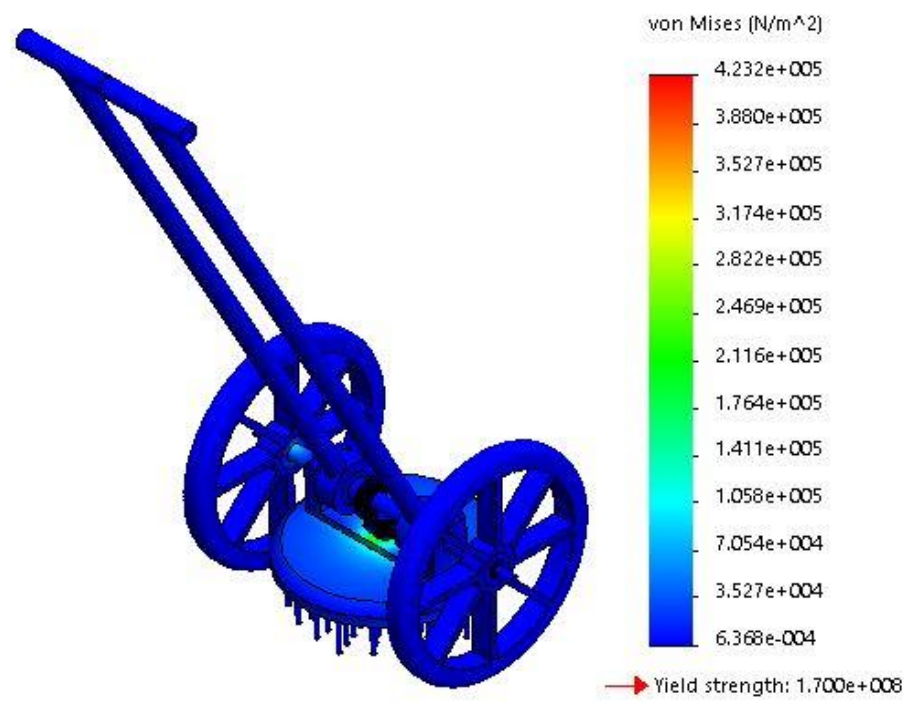

\section{Gambar 5. Hasil Stress Analysis}

Hasil strain analysis yang akan terjadi pada alat bantu pengerik garam yang ditunjukkan pada Gambar 6 akibat beban yang diterima tidak mempengaruhi bentuk atau merusak alat bantu. Berdasarkan hasil analisis strain/regangan diwakili dengan perubahan warna yang ditampilkan, dimana semakin berubah menuju ke arah warna merah regangan yang diterima semakin besar. Hasil perhitungan secara komputasi didapatkan regangan maksimum yang terjadi yaitu regangan yang ditunjukkan pada warna merah (1,007e-006 mm), sedangkan regangan minimum yang bekerja ditunjukkan dengan warna biru $(6,438 \mathrm{e}-015 \mathrm{~mm})$. Nilai yan dihasilkan tidak signifikan mempengaruhi bentuk dari pengerik garam. 


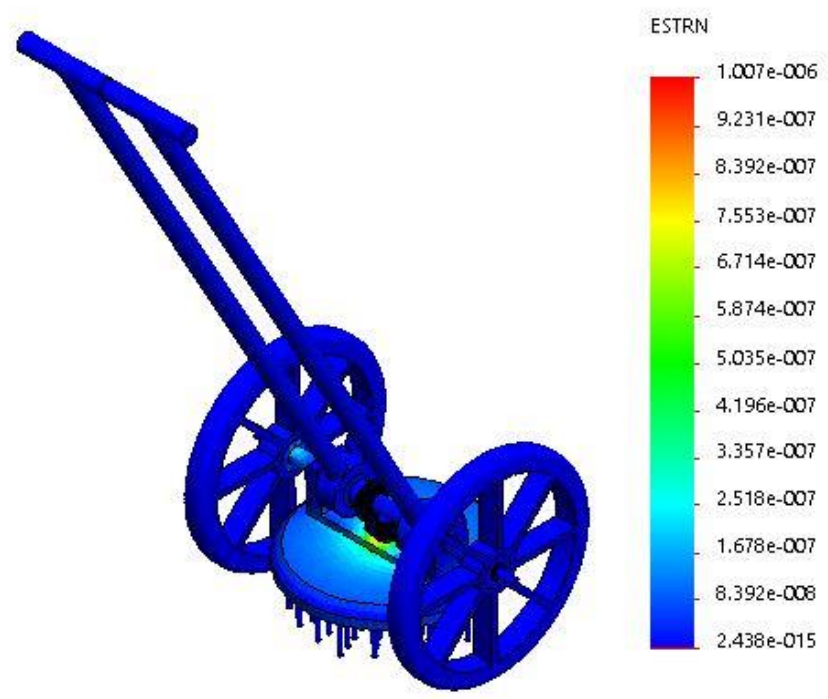

Gambar 6. Hasil Strain Analysis

Analisis safety factor merupakan analisis untuk memastikan bahwa alat benar-benar aman digunakan akibat pengaruh faktor internal dan eksternal. Faktor internal berasal dari tekanan dan daya dorong pada saat digunakan. Sedangkan faktor eksternal berasal dari kondisi endapan garam yang tidak bisa diprediksi akibat terbentuk secara alami. Nilai safety factor untuk alat bantu dan manufaktur adalah 1-1.5. Berdasarkan hasil analisis dengan komputasi dapat dilihat dari perubahan warna serta nilai safety factor yang ditnjukkan pada Gambar 7. Alat bantu pengerik memiliki nilai safety factor $4.017+\mathrm{e} 002$ lebih besar dari nilai ambang batas yaitu 1-1.5.A. Dengan demikian alat ini aman untuk digunakan dan comply. Hal ini dapat dilihat pada Gambar 7.

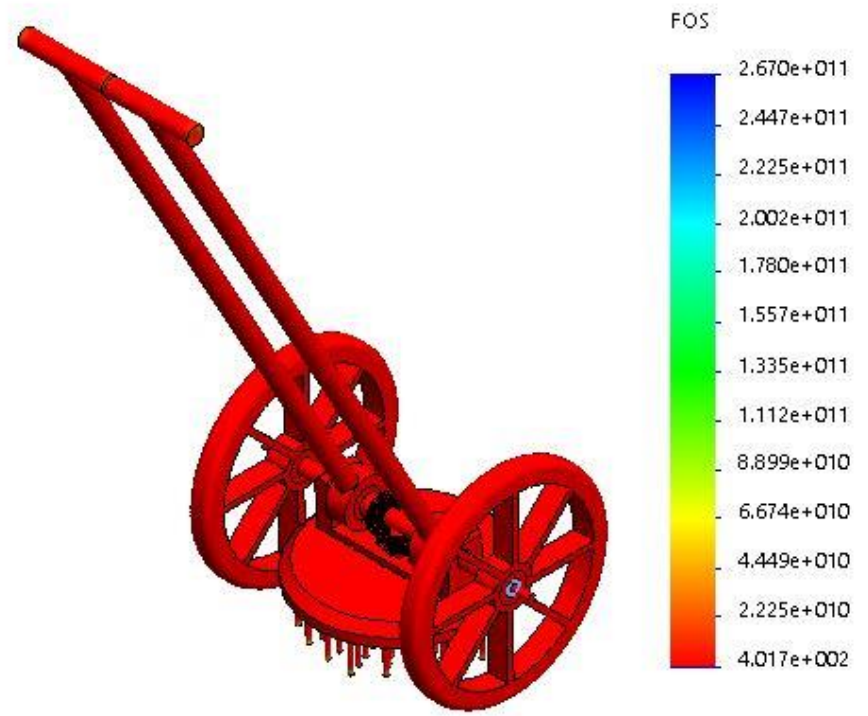

Gambar 7. Hasil Safety of Factor Analysis

\section{KESIMPULAN}

Dari pengambilan data yang sudah dilakukan, terdapat beberapa kesimpulan yang dapat dimunculkan antara lain,hasil perancangan mesin pengerik garam menggunakan taransmisi roda gigi kerucut lurus dapat merubah gerak horizontal menjadi axial sehingga menggerak pengerik garam yang berbentuk sikat. Berdasarkan hasil analisis dan simulasi memperlihatkan bahwa mesin pengerik garam ini bisa bekerja dengan baik dan aman digunakan dengan nilai safety factor $\geq 4$. 


\section{DAFTAR PUSTAKA}

[1] D. J. I. A. d. Kimia, "Kebijakan Pemerintah Indonesia dalam Hal Industri Garam," Kementerian Perindustrian, 2012.

[2] B. A. P. G. Indonesia, "http://statistik.kkp.go.id," 18 November 2017. [Online].

[3] A. Aligori, "Efisiensi Produksi Usaha Garam Rakyat Di Kabupaten Indramayu," Sekolah Pascasarjana Institut Pertanian Bogor, Bogor, 2013.

[4] B. P. Statistik, "Distribusi Perdagangan Komoditi Garam Indonesia 2014," Biro Pusat Statistik, Jakarta, 2014.

[5] H. Susanto, N. Rokhati dan Gunawan, "Ibm Kelompok Usaha Petani Garam Di Kabupaten Jepara: Pengembangan Proses Produksi Garam Untuk Peningkatan Kuantitas Dan Kualitas Produk," Majalah INFO, Vol. \%1 dari \%2Edisi XVI, Nomor 3, Oktober 2014.

[6] N. T. S. P. Jaya, R. Hartati, dan Widianingsih, "Produksi Garam Dan Bittern Di Tambak Garam," Jurnal Kelautan Tropis, vol. Vol. 19, no. (1), p. 43-47, Maret 2016.

[7] A. Wiraningtyas, A. Sandi, Sowanto dan Ruslan, "Pengingkatan Kualitas Garam Menjadi Garam Industri Di Desa Sanolo Kecamatan Bolo Kabupaten Bima," Jurnal Karya Abdi Masyarakat, vol. Volume 1 Nomor 2, 2017.

[8] R. R. Hidayat, "Rancang Bangun Alat Pemisah Garan Dan Air Tawar Dengan Menggunakan Matahari," Institut Pertanian Bogor, Bogor, 2011.

[9] Arwiyah, M. Zainuri dan M. Efendy, "Studi Kandungan Nacl Di Dalam Air Baku Dan Garam Yang Dihasilkan Serta Produktivitas Lahan Garam Menggunakan Media Meja Garam Yang Berbeda," Jurnal Kelautan, Vol. \%1 dari \%2Volume 8, No 1, April 2015.

[10] Sularso dan K. Suga, Dasar perancangan dan pemilihan elemen mesin, Bandung: PT.AKA, 1978. 